\title{
Family and Community as Protective Factors for Psychological Well-Being of Adolescents Survivors of Dating Violence
} A Literature Review

\author{
Annisa Zaenab Nur Fitria ${ }^{1 *}$, Marselius Sampe Tondok ${ }^{2}$ \\ ${ }^{1}$ Master of Professional Clinical Psychology, Surabaya University, Surabaya, Indonesia. \\ ${ }^{2}$ Faculty of Psychology, Surabaya University, Surabaya, Indonesia \\ *Corresponding author.Email: annisazaenab@gmail.com
}

\begin{abstract}
Accumulated research has shown that family and community play an essential role in maintaining the survivors' psychological well-being of any kind of violence. However, previous research has not systematized how the family and community can play a protective role for psychological well-being among adolescent dating violence survivors. The purpose of this study was to systematically review the role of family and community as protective factors for the psychological well-being of adolescent survivors of dating violence. A systematic search of four databases generated 12 studies meeting the exclusion and inclusion criteria. The results of the review show how family and community play an important role in providing a sense of security and courage for adolescent survivors of dating violence to ask for help. This protective role impacts the positive adjustment of adolescents in dealing with negative conditions experienced as survivors of violence, which in turn will have a positive impact on their psychological well-being. Implications of this study are discussed how the psychological intervention can be developed based on family and community strengths as protective factors for the psychological well-being of adolescent survivors of dating violence.
\end{abstract}

Keywords: Adolescence, Dating Violence, Family and Community, Literature Revies, Protective Factors.

\section{INTRODUCTION}

The body text starts with a standard first-level heading like INTRODUCTION or any other heading suitable to the content and context. First-level headings are in all caps. Copy the content and replace it with other first-level headings in the remaining text. Reference citations should be within square brackets [1]. Headings should always be followed by text.

This template, modified in MS Word 2007 and saved as a "Word 97-2003 Document" for the PC, provides authors with most of the formatting specifications needed for preparing electronic versions of their papers. All standard paper components have been specified for three reasons: (1) ease of use when formatting individual papers, (2) automatic compliance to electronic requirements that facilitate the concurrent or later production of electronic products, and (3) conformity of style throughout the conference proceedings.

"Dating violence" generally refers to attempts to dominate others by physical, sexual, or psychological control [1]. This condition harms individuals as survivors [2]. Adolescents are at risk of becoming survivors of violence compared to adults [3]. Research data shows that $65 \%$ of adolescent girls experience physical, emotional, and evensexual violence during their lifetime [2]. In this case, the cultural context is also a significant factor of violence in which women are considered a vulnerable group [4].

Related to resilience, women as survivors of violence experience a heavier impact than men [5] because women feel more burdened, especially emotionally than men [6]. As many as $87 \%$ of adolescent girls who survived violence tried to end 
their relationship, but they still felt the impact more severe. This is especially the case for teenagers who are survivors of violence, less able to control their surrounding environment [7]. In addition, adolescents have barriers to interacting with other people [8] because of an extraordinary fear of perceived negative consequences [9].

Adolescents who are survivors of violence fail to actualize their potential. This disability can be related to the social and environmental context [10]. The family and community environment have essential roles in improving the mental health stability of adolescent survivors of violence [11]. Psychological dynamics show that adolescent survivorsof violence are trying to get out of the feelings of guilt and unhappiness that have enveloped them [12]. The perceived negative influence certainly impacts psychological well-being, especially the affective aspect [5].

The World Health Organization (2013) reports that the prevalence of violence against teenagers is quickly growing globally. According to a survey in the United States, one out of four women has experienced violence at least once in her lifetime [13]. According to WHO data from 2013, adolescent violence is extremely common. Africa has thehighest percentage (36.6\%), followed by the Eastern Mediterranean (37\%) and Southeast Asia (37\%). (37.7 percent). In a survey undertaken by Baldwin in partnership with the Thomson Reuters Foundation in 63 countries, it was discovered that Indonesia is the third-worst country in terms of violence against women, after Saudi Arabia and India [14].

The Indonesian National Commission on Violence against Women noted an increase in cases of violence against women. In 2012 there were 216,156 cases and increase to 279,688 cases in $2013,293,220$ cases in 2014, and in 2017 there are 348,446 cases [15]. In 2017 there were 13,384 cases of violence against women reported, 1,873 of which were classified as dating violence [16].

Based on the information presented above, it is clear that violence against adolescents, particularly women, is a severe problem and can have various negative impacts. Violence survivors can suffer from various psychological traumas ranging from physical injury to post-traumatic stress disorder (PTSD), depression, anxiety, and even the desire to commit suicide [17]. Dating violence during adolescence or young adulthood can lead to involvement in intimate partner violence or domestic violence in adulthood [18].
Several researchers have tried to comprehend the various risk factors associated with the behavior of perpetrators of violence and survivors of dating violence.It aims to predict the parties most at risk and thus can devise measures to prevent or minimize the consequences [19]. As a result of intervention programs, most programs aim to increase understanding and modify attitudes about dating violence [20].

Adolescents who participate in intervention programs often report increased knowledge about dating violence and decreased attitudes that support dating violence [21]. Some researchers suggest that families and communities are supposed to help adolescent survivors of violence develop positively [22]. It also gives teenagers the opportunities to form healthy dating relationships [23].

Another study has found that aggressive adolescent relationship behavior is related to aggression tolerance insociety [24]. Similarly, some researchers suggest that the success of dating violence intervention programs can be increased by using an ecological approach in which individuals are consideredin the context of family, community, and society [25]. Overall, the studies suggest that researchersneed to examine the phenomenon of dating violence andits prevention by involving the role of family and community.

The majority of developmental psychology studies view the role of families, especially parents, as protective factors for adolescent survivors of dating violence [26]. For example, Richards et al. [6] show that a history of childhood abuse is one of the most significant risk factors for dating violence, both physically and psychologically. In addition, Maas et al.[27] found that the level of adolescent attachment with parents protects against victimization of dating violence.Other researchers have attempted to link the onset of violent behavior with social learning from parental aggression, insecure attachments due to poor parenting, and negative interactions or relationships between parents and offspring [10].

Several previous studies have investigated several factors that can increase the risk of dating violence. However, because families and communities are subsystems with direct contact with teenagers, exposureto parental hostility and social judgment of survivors of violence has attracted the greatest attention [13]. If a community does not provide a sense of security, adolescents may lack the courage to ask for helpwhen exposed to violence [28]. 
Family and community are the closest sub-systems to adolescents, therefore approaches to optimizing the role of families and communities can be used as a promotion, prevention, and curation intervention. Experts suggestthat the community has a significant role in dating violence cases and recommend that a community be included in violence intervention programs [29].

Two essential points may be noted in the preceding description. On the one hand, many psychological interventions have focused solely on the individual, ignored the importance of family and community empowerment in adolescent survivors of violence's psychological well-being. On the other hand, family and community are recognized to contribute to incidents or victimization that affect the psychological well-being of adolescent dating violence survivors. Therefore, the impact of family and community on the psychological well-being of adolescent dating violence survivors can be explored through this literature review. These findings are expected as the foundation for the development of family and community-based psychological interventions for adolescents as survivors of family and community-based violence.

\section{METHOD}

Styles can be applied using the style palette available within the template. To activate it the press Ctrl+Shift+s. Apply the style as required based on the content and context. (Please don't highlight your text in yellow.)

To achieve the objectives of this study, a literature review method was used with reference to the PRISMA (Preferred Reporting Items for Systematic Reviews and Meta-Analyses) protocol [30]. This study analyzed previous studies on the psychological wellbeing ofadolescent survivors of violence and the role of family and community as protective factors.

Data sources were obtained through various journal databases: Science Direct, NCBI, Google Scholar, and Springer Link. The keywords used are "family and community" and "adolescence dating violence." The search was carried out from April 16 to April24, 2021. The initial stage of reference selection was obtained by 50 journal articles based on keywords. Based on the title, abstract, and exclusion criteria, 30 journal articles were obtained. A comprehensive review of the research and based on the inclusion criteria obtained 12 journal articles. The process of selecting journal articles is shown in Figure 1.

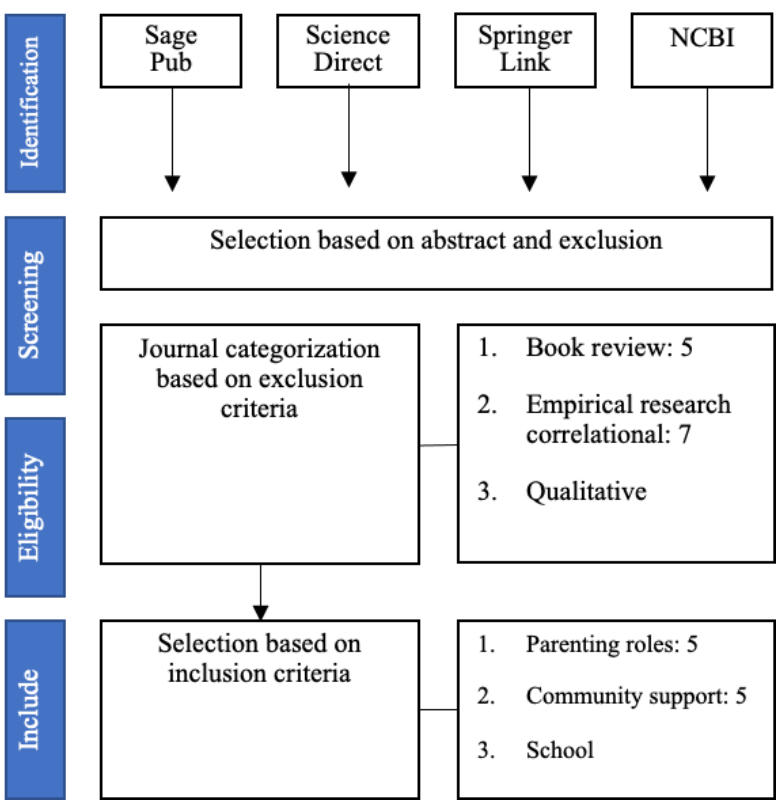

Figure 1. Journal Article Selection Process Chart

The inclusion criteria for articles selection are: first, the research subjects are at the stage of adolescent development (11-20 years) and have been exposed to violence. Second, in this study, the intervention involved parents and the community in the process. Third, journalsare written in English or translated into English. Fourth, the article is empirical research and not a literature study. Fifth, articles published in the last 10 years (2011-2021).Sixth, the article has been published by a reputable international or national journal.

Meanwhile, the exclusion criteria for an article to fulfil the requirementsfor writing a systematic literature review on this topic are:First, the subject of research outside the stages of adolescent development. Second, the article is a literaturereview study or meta-analysis. Fourth, the articles come from unreputed journals.

\section{RESULT}

Results of the review of 12 journal articles based on author and year of publication, the sample used, age of participants, and the results of the whole study are summarized in Table 1. The results of the selection of journal articles based on inclusion and exclusion criteriainvolved 12 journals with a total of 10,684 participants and were categorized by age, research context, and research results. 
Table 1. Studies Summary

\begin{tabular}{cccc}
\hline Total & Tothor & Family/ & Community \\
and Age & Domain & Location & Result \\
\end{tabular}

\begin{tabular}{|c|c|c|c|c|c|}
\hline \multirow[t]{2}{*}{$\begin{array}{l}\text { (Foshee et } \\
\text { al., 2015) }\end{array}$} & $\begin{array}{l}\text { Mother and } \\
\text { adolescent } \\
\text { pairs }(\mathrm{N}\end{array}$ & \multirow[t]{2}{*}{$\begin{array}{l}\text { Positive } \\
\text { Parenting }\end{array}$} & \multirow[t]{2}{*}{ USA } & \multirow{2}{*}{$\begin{array}{l}\text { Moms and Teens } \\
\text { for Safe Dates is a } \\
\text { programfor a } \\
\text { mother who has } \\
\text { been a victim of } \\
\text { domestic violence } \\
\text { to conduct } \\
\text { prevention } \\
\text { socialization for } \\
\text { teenagers exposed } \\
\text { toabuse. }\end{array}$} & \multirow{2}{*}{$\begin{array}{l}\text { The MTSD } \\
\text { intervention program } \\
\text { had a significant } \\
\text { effect on survivorship } \\
\text { (defined as 1 SD } \\
\text { above mean) }(\mathrm{b}=- \\
0.8311, \mathrm{p}=.518) \\
{[35] .}\end{array}$} \\
\hline & $\begin{array}{l}=409) ; 12-16 \\
\text { yearsold }\end{array}$ & & & & \\
\hline
\end{tabular}

\begin{tabular}{|c|c|c|}
\hline $\begin{array}{l}\text { (Laporte et } \\
\text { al., 2011) }\end{array}$ & $\begin{array}{l}471 \text { teens } \\
12-19 \text { years } \\
\text { old }\end{array}$ & $\begin{array}{l}\text { Negative } \\
\text { parenting }\end{array}$ \\
\hline
\end{tabular}

Families with violence-dominated parenting impact the presence of violent behavior, which will be replicated by children as teenagers.
The data show that adolescents bring childhood experiences with family violence into their intimate relationships $(.<0.2)$ and estimate 0.02 [34].

\begin{tabular}{|c|c|c|c|c|}
\hline $\begin{array}{l}\text { (Rowe et } \\
\text { al., 2015) }\end{array}$ & $\begin{array}{l}83 \text { teenage } \\
\text { girls ingrade } \\
12 \text { high school }\end{array}$ & $\begin{array}{l}\text { Community } \\
\text { Support }\end{array}$ & $\begin{array}{l}\text { Southwestern } \\
\text { City, USA }\end{array}$ & $\begin{array}{l}\text { Community efforts } \\
\text { include developing } \\
\text { a web-based dating } \\
\text { violence prevention } \\
\text { method called My } \\
\text { Voice My Choice, } \\
\text { which teaches } \\
\text { young girls how to } \\
\text { reject dating } \\
\text { violence firmly. }\end{array}$ \\
\hline
\end{tabular}

Data revealed the main effect condition: MVMC experimental group participants were more likely to report problems than control group participants, $\mathrm{b}=.77, \mathrm{OR}=.47, \mathrm{t}$ $(70)=2.29$, p b .05 [25].

\section{Adolescents with} parents with a high intimate partner

610 parents with their (Liu et al., children in a 2018) relationship (aged12-21 years)
Parents who tend to be harsh in their interactions can threaten teenagers to fall into dating violence cases. victimization category were 4 times more likely to commit violence in their relationship (probability ARA = 0.80 for high IPV vs. 0.50 for low IPV) [11]. 


$\begin{array}{llll} & \begin{array}{l}\text { Adolescent } \\ \text { (Richards }\end{array} & & \\ \text { girls with } & \text { Family } & \text { Ohio, USA } \\ \text { et al., } & \text { divorced } & \text { dissolution } & \\ \text { families }(\mathrm{n}= & & \\ & 346) & \end{array}$

Family dissolution can lead to effects such asdepression and adjustment disorders. In this case, poor family integrity can affect how adolescents interpret warmth in relationships.

Major Parents' aggressive universities in behavior will Southeast determinehow Asiaregion

teenagers will behave when in a dating relationship. Two types of parental aggression: hostility between parents and inconsistent parenting between father and mother.
$22 \%$ of the sample indicated that they had physically abused their partner, while almost $16 \%$ were survivors of violence. Family divorce can be associated with the possibility of adolescent involvement in cases of dating violence [6].

Conflicting parents affect adolescents' tendency to become perpetrators of dating violence $(b=.12, p$ > $.05)$. On the other hand, parental warmth showed an effect $(b=$ $.32, \mathrm{p}<.01)$ for the tendency of adolescents to become perpetrators of dating violence [38].

\begin{tabular}{|c|c|c|c|}
\hline $\begin{array}{ll}\text { (Storer etal., } & \text { Total } \\
\text { 2017) } & \text { participants } \\
& (\mathrm{n}=39) ; \text { age } \\
& \text { range } 17-22 \\
& \text { years. }\end{array}$ & $\begin{array}{l}\text { Community } \\
\text { support }\end{array}$ & $\begin{array}{l}\text { New Orleans, } \\
\text { USA }\end{array}$ & $\begin{array}{l}\text { Bystander effect } \\
\text { intervention } \\
\text { programs at the } \\
\text { school and } \\
\text { community levels } \\
\text { can be a focus for } \\
\text { community-based } \\
\text { dating violence } \\
\text { interventions. The } \\
\text { community can play } \\
\text { a rolein preventive } \\
\text { and curative efforts. }\end{array}$ \\
\hline
\end{tabular}

Research identifies the right combination of factors (defining the problem situation, individual responsibility for action) to increase proactive attitude [42]. a rolein preventive and curative efforts.

\begin{tabular}{|c|c|c|c|c|c|}
\hline $\begin{array}{l}\text { (Foshee et } \\
\text { al., 2012) }\end{array}$ & $\begin{array}{l}\text { Experimental } \\
\text { groupn=230; } \\
\text { control group } \\
\mathrm{n}=234\end{array}$ & $\begin{array}{l}\text { Positive } \\
\text { parentingAdult } \\
\text { non-parental } \\
\text { support }\end{array}$ & $\begin{array}{l}\text { Chapel Hill, } \\
\text { North } \\
\text { Carolina,USA }\end{array}$ & $\begin{array}{l}\text { The family has a } \\
\text { significant influence } \\
\text { on risk factors for } \\
\text { violence. The } \\
\text { influence of family } \\
\text { and caregivers in } \\
\text { terms of interaction } \\
\text { patternswith } \\
\text { adolescents } \\
\text { continues. }\end{array}$ & $\begin{array}{l}\text { There was a significant } \\
\text { treatment effect } \\
(.<0.05) \text {. The factor } \\
\text { that motivates and } \\
\text { facilitates the welfare } \\
\text { of adolescents is the } \\
\text { involvement of } \\
\text { caregivers in } \\
\text { preventing dating } \\
\text { violence inadolescents } \\
{[36] \text {. }}\end{array}$ \\
\hline
\end{tabular}




\begin{tabular}{|c|c|c|c|c|c|}
\hline $\begin{array}{l}\text { (Storer etal., } \\
\text { 2017) }\end{array}$ & $\begin{array}{l}\text { Via online } \\
\text { groups }(n=60) ; \\
\text { Directly }(n=53) \text {. } \\
\text { Age range } 14 \text { - } \\
17 \text { years }\end{array}$ & $\begin{array}{l}\text { School } \\
\text { Attachment }\end{array}$ & $\begin{array}{l}\text { Washington } \\
\text { State, USA }\end{array}$ & $\begin{array}{l}\text { Bystander effect } \\
\text { intervention } \\
\text { program empowers } \\
\text { youth to take part } \\
\text { proactively when } \\
\text { they witness } \\
\text { bullying and dating } \\
\text { violence in their } \\
\text { social environment. }\end{array}$ & $\begin{array}{l}\text { Factors at school: } \\
\text { trusting relationships } \\
\text { with teachers; positive } \\
\text { perception of school } \\
\text { personnel,positive } \\
\text { response, a school } \\
\text { environment that is } \\
\text { tolerant of violence } \\
\text { cases and ineffective } \\
\text { school policies [42]. }\end{array}$ \\
\hline $\begin{array}{l}\text { (Oscós- } \\
\text { Sánchez et } \\
\text { al., 2021) }\end{array}$ & $\begin{array}{l}\text { Young Adults; } \\
\text { Students; Parent }\end{array}$ & $\begin{array}{l}\text { Community } \\
\text { Support }\end{array}$ & USA & $\begin{array}{l}\text { Programs that } \\
\text { address family, } \\
\text { school, and } \\
\text { community } \\
\text { systems are more } \\
\text { effective because } \\
\text { the sub-micro can } \\
\text { stabilize the } \\
\text { psychological well- } \\
\text { being of survivors } \\
\text { from various } \\
\text { perspectives. }\end{array}$ & $\begin{array}{l}\text { CBPR can be used to } \\
\text { actively involve youth } \\
\text { and in implementi } \mathrm{g} \\
\text { primary intervention } \\
\text { programs. VPP had a } \\
\text { positive effect on } \\
\text { violence at } 12 \text { months, } \\
\text { and PYDP had a } \\
\text { positive effect on } \\
\text { violence at school at } 6 \\
\text { months [43]. }\end{array}$ \\
\hline $\begin{array}{l}\text { (Pérez- } \\
\text { Martínez et } \\
\text { al., 2020) }\end{array}$ & $\begin{array}{l}1,555 \\
\text { participants } \\
(13-16 \text { years })\end{array}$ & $\begin{array}{l}\text { School } \\
\text { Attachment }\end{array}$ & $\begin{array}{l}\text { Romania, } \\
\text { NewYork, } \\
\text { Spanyol }\end{array}$ & $\begin{array}{l}\text { Teachers have a } \\
\text { unique role in } \\
\text { providing social } \\
\text { support, } \\
\text { encouraging } \\
\text { positive } \\
\text { development } \\
\text { through positive } \\
\text { acceptance of } \\
\text { survivors. }\end{array}$ & $\begin{array}{l}\text { Students who received } \\
\text { higher parental and } \\
\text { teacher social support } \\
\text { levels scored lower on } \\
\text { exposure to violence } \\
\text { [44]. }\end{array}$ \\
\hline
\end{tabular}

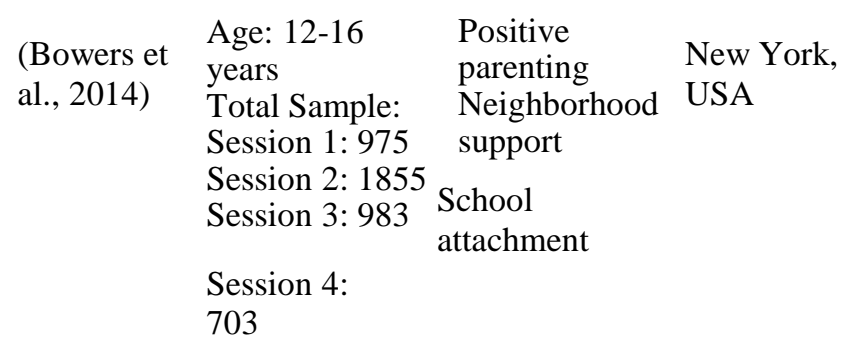

Support from adults who are not parents is also important, just as extended family, teachers, mentors, coaches, and neighbors also, increase the level of PYD (positive youth development).
The closeness between adolescents and adults to talk about some or all of the problems experienced by adolescents is associated with an increase in psychological wellbeing, which has a significant effect $(<$ $0.5)$ [45].

Note: $V P P=$ Violence Prevention Program $; P Y D P=$ Positive Youth Development Program; $C B P R=$ Community-Based Participatory Action Research; MTSD =Moms and Teens for Safe Dates; $M V M C=M y$ Voice My Choice; IPV= intimate partner victimization 


\section{DISCUSSION}

Figures and tables should be placed either at the top or bottom of the page and close to the text referring to them if possible.

This literature review research is focused on studying the role of family and community as a protective factor for the psychological well-being of adolescent survivors of violence. Most of the previous empirical research has focused more on exploring the contribution of childhood experiences to violent behavior in later life [25] and the intervention process for adolescent survivors of violence with an individual approach [31], [32], [33].

The findings of this study are significant in examiningthe psychological well-being of adolescent survivors of violence using the family and community approach as a protective factor. Researchers identified specific factors that predict violent behavior triggered by personal formation through family parenting. In line with the research background, these factors include: (1) parenting, (2) communication patterns, and (3) the structure of family members. These factors are similar for perpetrators and victims. This study determined the strongest predictor of the incidence of dating violence by comparing the predictive power of family and community review factors. Based on these findings, the strongest protective factor is family communication patterns, while witnessing between parents predicts dating violence victimization.

Furthermore, the researchers found that protective factors were critical in the intervention of adolescent survivors of dating violence to reduce risk factors. Although family and parent-related factors have received more attention concerning interpersonal violence so far, previous studies showed that community-related factors (e.g., school, peers, and environment) should also be considered for various prevention strategies. The findings of this study provide strong evidence for developing various interventions to preventdating violence, in line with the research aim that focuses on the domain of family and community. The family domain includes factors related to parents, family, and childhoodexperiences, while the community domain includes factors related to peers, school, and the environment.

In Table 1, family parenting patterns that have problems in relationships or interactions, family structure, to negative parenting such as childhood abuse can trigger teenagers to become perpetrators of violence or victims of dating violence. Among these factors, family relationship problems, negative parenting, and witnessing violence between parents positively predicted the occurrence of violence in children later in life. A study conducted by [34] shows that adolescents will adapt the violence experienced by adolescents during childhood into their relationships $(.<0.2)$ and the estimated score is 0.02 .

The same thing is shown by research (Liu et al., 2018) that adolescents with high intimate partner victimization parents are four times more likely to commit dating violence (probability $\mathrm{ARA}=0.80$ for intimate partner violence vs 0.50 for low intimacy partner violence) [11]. However, the family also plays a role as a protective factor for adolescent violence survivors. Research conducted by Foshee et al. [35] stated that the programinitiated by Mom and Teens for Safe Dates had a significant effect on victims (defined as $1 \mathrm{SD}$ above average) $(\mathrm{b}=-0.8311, \mathrm{p}=0.518)$. In this program, young girls and their mothers are given equal rights to share their experiences as survivors of violence.

Openness in the family contributes to creating a sense of security in adolescents telling their experiences of violence. Foshee et al. [36] also conducted a similar study by involving caregivers who were adults other than parents in the family. The results showed a significant treatment effect $(<0.05)$; it is known that the motivating factor and facilitating the welfare of adolescents is the involvement of caregivers in preventing dating violence in adolescents.

Family plays an essential role as the foundation of adolescent mental health [37], especially psychological well-being. As previously explained, adolescents' closeness to their parents can contribute to how adolescents make choices and behave when exposed to violent conflict [38]. Well-being is often understood as a diverse construct, such as life satisfaction, happiness, subjective well-being, psychological well-being, and quality of life.

Indicators related to well-being consist of positive affect and the absence of negative affect. Individuals canbe said to have good functioning marked by the presenceof self-esteem (self-esteem), life satisfaction (life satisfaction), happiness (happiness), selfacceptance (self-acceptance), positive relationships, and personal growth [39]. Protective factors, which are described as factors that can reduce the negative impact of existing threats, focus on the role of families and communities in this study. Both of these are formulated to reduce and even prevent the threat, namelyviolence in dating. 
Families can comprehensively contribute to the well-being of adolescents. McKeown (2003) revealed that thewelfare of children and parents is divided into two groups of factors, namely direct and indirect. Factors that have adirect influence are divided into the functioning of the family, personality, and the socioeconomic environmentof the family. At the same time, the factors that have an indirect influence are the support of grandparents and the category of social class [40].

In the community context, which also plays an essential role as a protective factor for adolescent violence survivors, it is more directed to service providers and provides a safe environment. Considering that social assessment also has negative consequences foradolescent survivors of violence who psychologically need support [41]. In Table 1, the research conducted by Rowe et al., [25] on community efforts, namely carrying out preventive interventions through the My Voice My Choice website, shows the results that the MVMC experimental group participants tend to report the problems they face related to violence openly compared to the control group $b=.77$, OR $=.47, t(70)=2.29, \mathrm{pb} .05$. The MVMC intervention is packaged with a bystander intervention adaptation. In this intervention, adolescents do not know the counsellor's identity to whom they tell stories. This can trigger youth's openness regarding the experience of violence.

The school context also contributes to the psychological well-being of adolescents. Research conducted by Pérez-Martínez et al. [44] (2020) shows that students who received high levels of social support frompeers and teachers showed low scores on exposure to violence. In this case, schools can play a role in preventing violence. Student trust with school members also plays an important role. Research conducted by Storer et al. [42] shows that factors in schools are trusting relationships with teachers, positive perception of school personnel, positive response, a school environment that is tolerant of cases of violence and ineffective school policies.

Adolescent survivors of violence need to be taught tohave the courage to ask for help [46]. Community in scope: neighbors and schools can play a role in this [47]. Social changes in people's lives significantly affect adolescents' sense of security as survivors of dating violence [43].

Many studies have investigated the contribution of family factors to dating violence in various samples. So far, it is still unclear which family factors contribute the most to the incidence or victimization of dating violence. Although the contribution of community- related factors is relatively negligible, several studies predict individual protective factors as survivors of dating violence, namely concerning peer relationships, friendship quality, school attachments, or environmentalconditions [24].

Responding to problems related to violence, the researcher examines several predictions of protective factors that can answer the problem as a solution.In the synthesis of this protective factor review, the researcher categorizes it into three sub-categories, namely (1) the family context, which can include parentsand siblings, (2) the community context, in this case, it includes peers and school situations that support individuals.

The findings from this study can be used by individuals to develop policies and programs to prevent dating violence through family and community environments. Most members of the community and families need to be mobilized to provide a sense of security and foster the courage of adolescent survivors ofviolence to open up about their experiences (Storer et al.,2021b) [48].

In the context of the community, knowledge and attitudes about the prevalence, severity, and causes of cases of violence in local communities affect the ability to introduce effective programs. For this reason, it is necessary to have an assessment before the implementation of the prevention program.

\section{CONCLUSION}

Community and family are crucial factors for individual development. Previous research has shown anessential role in the condition of the community or environment around the perpetrators and victims during the growth period. The environmental factors most oftenconsidered are those related to family and parents, although few studies have considered factors related to the individual's community.

It can be considered that family and community are very crucial environments for the psychological wellbeing of adolescents as survivors of violence. Family andcommunity are places where individuals learn how to behave or interact with other people, namely family, school, peer groups, and the workplace as microsystems. This microsystem is where teenagers spend most of theirtime socializing and performing daily activities. Thus, families and communities are a place for teenagers to learn naturally and adopt positive behavior to become provisions for the future. 


\section{SUGGESTION}

Figures and tables should be placed either at the top or bottom of the page and close to the text referring to them if possible.

The findings of this study are considered helpful for psychology professionals, parents, and educators in contributing to adolescent survivors of violence. Families and communities can provide emotional support to adolescent survivors of dating violence.

Families and communities can play a role as protective factors for adolescent survivors of violence in improving their psychological well-being, especiallybeing more concerned about themselves as survivors. Thus, families and communities can create a sense of security for adolescents in telling about incidents of violence they have experienced, dare to ask for help when adolescents feel they need help, and gradually recover from the trauma experienced as survivors of violence.

\section{REFERENCES}

[1] Viejo, C., Monks, C. P., Sánchez, V., \& OrtegaRuiz, R., Physical dating violence in Spain and the United Kingdom and the importance of relationship quality, Journal of Interpersonal Violence, 2016, 31(8), $\quad$ pp. 1453-1475. DOI:

https://doi.org/10.1177/0886260514567963

[2] Bonache, H., Ramírez-Santana, G., \& GonzalezMendez, R., Estilos de resolución deconflictos y violencia en parejas de adolescents, International Journal of Clinical and Health Psychology, 2015, 16(3), pp. 276-286. DOI:

https://doi.org/10.1016/j.ijchp.2016.03.003

[3] Clayton, H. B., Lowry, R., Basile, K. C., Demissie, Z., \& Bohm, M. K., Physical and sexual dating violence and nonmedical use of prescriptiondrugs, Pediatrics, 2017, 140(6). DOI: https://doi.org/10.1542/peds.2017-2289

[4] Safitri, W. A., \& Sama'i, D., Dampak kekerasan dalam berpacaran (the impact of violence in dating), Artikel Ilmiah Hasil Penelitian Mahasiswa UNEJ, 2013, 1(1), pp. 1-6.

[5] Cascardi, M., From violence in the home to physical dating violence victimization: the mediating role of psychological distress in a prospective study of female adolescents, Journal ofYouth and Adolescence, 2016, 45(4), pp. 777792. DOI: https://doi.org/10.1007/s10964-0160434-1

[6] Richards, T. N., Branch, K. A., \& Ray, K., The impact of parental and peer social support on dating violence perpetration and victimization among female adolescents: A

longitudinal study, Violence and victims, 2014, 29(2), pp. 317-331. DOI: https://doi.org/10.1891/0886-6708.VV-D-1200141R1

[7] Giordano, P. C., Johnson, W. L., Manning, W. D., \& Longmore, M. A., Parenting in adolescence and young adult intimate partner violence, 2016, Journal of Family Issues, 37(4), pp. 443-465. DOI:

https://doi.org/10.1177/0192513X13520156

[8] Ansara, D.L., \& Hindin, J.L., Psychosocial Consequences of Intimate Partner Violence for Women and Men in Canada, Journal of Interpersonal Violence, 2011, 26(8), pp. 16281645.

[9] Adamsons, K. \& Johnson, S. K., An updated and expanded meta-analysis ofnonresident fathering and child well-being, Journal of Family Psychology, 2013, 27(4), pp. 589-599. DOI: https://doi.org/10.1037/a0033786

[10] DeGue, S., Valle, L. A., Holt, M. K., Massetti, G. M., Matjasko, J. L., \& Tharp, A. T., A systematic review of primary prevention strategies for sexual violence perpetration, Aggression and Violent Behavior, 2014, 19(4), pp. 346-362. DOI: https://doi.org/10.1016/j.avb.2014.05.004

[11] Liu, W., Mumford, E. A., \& Taylor, B. G., The relationship between parents' intimate partner victimization and youths' adolescent relationship abuse, Journal of Youth and Adolescence, 2018, 47(2), pp. 321-333. DOI: https://doi.org/10.1007/s10964-017-0733-1

[12] Cava, M. J., Buelga, S., \& Tomás, I., Peer victimization and dating violence victimization: themediating role of loneliness, depressed mood, and life satisfaction, Journal of Interpersonal Violence, 2021, 36(5-6), pp. 2677-2702. DOI: https://doi.org/10.1177/0886260518760013

[13] Black, D. S., Sussman, S., \& Unger, J. B., A further look at the intergenerational transmission ofviolence: Witnessing interparental violence in emerging adulthood, Journal of Interpersonal Violence, 2010, 25, pp. 1022-1042.

[14] Baldwin, K. Canada best G20 country to be a woman, India worst, 2012. Retrieved from: https://www.reuters.com/article/g20-womenidINDEE85C00420120613

[15] Komnas Perempuan, Labirin kekerasan terhadap perempuan: Dari gang rape hingga femicide, 
alarm bagi negara untuk bertindak tepat, catatan KTP 2016, 2017. Retrieved from: https://www.komnasperempuan.go.id/file/pdf_fi le/2017Siaran Pers/Lembar Fakta Catahu 2017.pdf

[16] Komnas Perempuan, Tergerusnya ruang aman perempuan dalam pusaran politik populisme, catatan KTP 2017, 2018. Retrieved from https://www.komnasperempuan.go.id/file/pdf_fi le/ 2018/Publikasi/Catatan Tahunan Kekerasan Terhadap Perempuan 2018.pdf

[17] Pill, N., Day, A., Mildred, H., Trauma responses to intimate partner violence: A review of current knowledge, Elsevier, 2017, (34), pp. 178-184.

[18] Sabina, C., Cuevas, C. A., \& Cotignola-Pickens, H. M., Longitudinal dating violence victimization among Latino teens: Rates, risk factors, and cultural influences, Journal of Adolescence, 2016, 47, pp. 5-15. DOI: https://doi.org/10.1016/j.adolescence.2015.11.0 03

[19] East, P. L., Chien, N. C., Adams, J. A., Hokoda, A.,\& Maier, A., Links between sisters' sexual and dating victimization: The roles of neighborhood crime and parental controls, Journalof Family Psychology, 2010, 24(6), pp. 698-708.

DOI: https://doi.org/10.1037/a0021751

[20] Morelli, M., Bianchi, D., Chirumbolo, A., \& Baiocco, R., The cyber dating violence inventory. Validation of a new scale for onlineperpetration and victimization among dating partners, European Journal of DevelopmentalPsychology, 2018, 15(4), pp. 464-471. DOI: https://doi.org/10.1080/17405629.2017.1305885

[21] Ball, B., Rosenbluth, B., \& Aoki, A., The expect respect program manual part I: Support group curriculum and facilitator guide, SafePlace, 2008.

[22] Izaguirre, A., \& Calvete, E., Exposure to family violence as a predictor of dating violence and child-to-parent aggression in Spanish adolescents, Youth and Society, 2017, 49(3), pp. 393-412.

DOI: https://doi.org/10.1177/0044118X16632138

[23] Jouriles, E. N., Rosenfield, D., Yule, K., Sargent, K. S., \& McDonald, R., Predicting high- school students' bystander behavior in simulated dating violence situations, Journal of Adolescent Health, 2016, 58(3), pp. 345-351. DOI:https://doi.org/10.1016/j.jadohealth.2015.1 1.009

[24] Ellsberg, M., Ullman, C., Blackwell, A., Hill, A.,
\& Contreras, M., What works to prevent adolescent intimate partner and sexual violence? A global review of best practices. In Adolescent Dating Violence: Theory, Research, and Prevention. Elsevier Inc, 2018. DOI: https://doi.org/10.1016/B978-0-12-8117972.00016-5

[25] Rowe, L. S., Jouriles, E. N., \& McDonald, R., Reducing sexual victimization amongadolescent girls: A randomized controlled pilot trial of my voice, my choice, Behavior Therapy, 2015, 46(3), pp. 315-327. DOI: https://doi.org/10.1016/j.beth.2014.11.003

[26] Gul, H., Gul, A., Yurumez, E., \& Öncü, B., Voices of adolescent incest victims: A qualitative study on feelings about trauma and expectations of recovery, Archives of Psychiatric Nursing, 2020, 34(2), pp. 67-74. DOI: https://doi.org/10.1016/j.apnu.2020.02.003

[27] Maas, C. D., Fleming, C. B., Herrenkohl, T. I., \& Catalano, R. F., Childhood predictors of teen dating violence victimization, Violence and Victims, 2010, 25(2), pp. 131149. DOI: https://doi.org/10.1891/0886$\underline{6708.25 .2 .131}$

[28] Cuartas, J., \& Leventhal, T., Exposure to community violence and children's mental health: A quasi-experimental examination, Social Science andMedicine, 2020, 246 (May 2019), 112740.

DOI:https://doi.org/10.1016/j.socscimed.2019.1 $\underline{12740}$

[29] Lourenço, R. G., Fornari, L. F., Santos, D. L. A Dos, \& Fonseca, R. M. G. S. da., Community interventions related to intimate partnerviolence among adolescents: scope review. Revista Brasileira de Enfermagem, 2019, 72(1), pp. 277 286. DOI: https://doi.org/10.1590/0034-71672018-0586

[30] Moher, D., Liberati, A., Tetzlaff, J., Altman, D.G.,The PRISMA Group, Preferred reporting items for systematic reviews and meta-analyses: the prisma statement. PLoS Med., 2009, 6(7): e1000097.

DOI: https://doi.org/10.1371/journal.pmed.1000097

[31] Mesra, E. M., Salmah, S. S., \& Fauziah, F. F.Kekerasan dalam pacaran pada remaja putridi Tangerang, Jurnal Ilmu Dan Teknologi Kesehatan,

2014,2(1),pp.18.DOI:http://www.ejurnal.poltek kesjakarta3.ac.id/index.p $\mathrm{hp} / \mathrm{jitek} /$ article/view/115

[32] Nurislami, N. R., \& Hargono, R., Kekerasan 
dalam pacaran dan gejala depresi pada remaja, Jurnal Promkes, 2014, 2(2), pp. 173-185.

[33] Sari, I. P., dalam relasi pacaran. Perempuan korban cenderung menjadi makhluk irasional dengan mempertahankan relasi pacarannya dengan pertimbangan keuntungan berupa terhindar dari, Jurnal Dimensia, 2018, 7(1), pp. 64-85. DOI: file:///C:/Users/user/Downloads/21055-52405-1PB (2).pdf

[34] Laporte, L., Jiang, D., Pepler, D. J., \& Chamberland, C., The relationship between adolescents' experience of family violence and dating violence, Youth and Society, 2011, 43(1), pp. 3-27. DOI: https://doi.org/10.1177/0044118X09336631

[35] Foshee, V. A., Benefield, T., Dixon, K. S., Chang, L. Y., Senkomago, V., Ennett, S. T., Moracco, K. E., \& Bowling, J. M., The effects of moms and teens for safe dates: A dating abuse prevention program for adolescents exposed to domestic violence, Journal of Youth and Adolescence, 2015, 44(5), pp.995-1010. DOI: https://doi.org/10.1007/s10964-015-0272-6

[36] Foshee, V. A., McNaughton Reyes, H. L., Ennett, S. T., Cance, J. D., Bauman, K. E., \& Bowling, J. M., Assessing the effects of families for safe dates, a family-based teen dating abuse prevention program, Journal of Adolescent Health, 2012, 51(4), pp. 349-356. DOI: Htps://doi.org/10.1016/j.jadohealth.2011.12.029

[37] Fowler, J., \& Christakis, N., Estimating Peer Effects on Health in social networks : a response to cohen-cole and fletcher; trogdon, nonnemaker, pais, J Health Econ, 2008, 27(5), pp. 1400-1405. DOI: 10.1016/j.jhealeco.2008.07.001

[38] Simons, L. G., Simons, R. L., Lei, M. K., Hancock, D. L., \& Fincham, F. D., Parental warmth amplifies the negative effect of parental hostility on dating violence, Journal of Interpersonal Violence, 2012, 27(13), pp. 2603-2626. DOI: https://doi.org/10.1177/0886260512436387

[39] Diener, E., Oishi, S., \& Lucas, R., Personality, culture, and subjective well-being: emotional and cognitive evaluations of life, Annual Review of Psychology, 2003, 54, pp. 403-425. DOI: https://doi.org/10.1146/annurev.psych.54.10160 1.145056

[40] McKeown, K., Using evidence to develop services for children and families: some considerations and challenges for the child \& family support agency, Journal of the Institute of
Public Administration, 2013, 61(1), pp. 1-43.

[41] Storer, H. L., McCleary, J. S., \& Hamby, S., When it's safer to walk away: Urban, low opportunity emerging adults' willingness to use bystander behaviors in response to community and dating violence, Children and Youth Services Review, 121(August 2020), 2021, 105833.

DOI: https://doi.org/10.1016/j.childyout.2020.105833

[42] Storer, H. L., Casey, E. A., \& Herrenkohl, T. I., Developing "whole school" bystander interventions: The role of school-settings in influencing adolescents responses to dating violence and bullying, Children and Youth ServicesReview, 2017, 74, pp. 87-95. DOI:

https://doi.org/10.1016/j.childyouth.2017.01.018

[43] Oscós-Sánchez, M. Á., Lesser, J., Oscós-Flores, L. D., Pineda, D., Araujo, Y., Franklin, B. Hernández, J. A., Hernández, S., \& Vidales, A., The effects of two community-based participatory action research programs on violence outside of and in school among adolescents and young adults in a Latino community, Journal of Adolescent Health, 2021, 68(2), pp. 370-377. DOI: https://doi.org/10.1016/j.jadohealth.2020.10.004

[44] Pérez-Martínez, V., Sanz-Barbero, B., FerrerCascales, R., Bowes, N., Ayala, A., SánchezSanSegundo, M., Albaladejo-Blázquez, N. Rosati, N., Neves, S., Pereira Vieira, C., Jankowiak, B., Waszyńska, K., \& Vives-Cases, $\mathrm{C}$., The roleof social support in machismo and acceptance of violence among adolescents in Europe: Lights violence baseline results, Journal of Adolescent Health, 2020， 68, pp. 922929.

DOI: https://doi.org/10.1016/j.jadohealth.2020.09.007

[45] Bowers, E. P., Johnson, S. K., Buckingham, M. H.,Gasca, S., Warren, D. J. A., Lerner, J. V., \& Lerner, R. M., Important non-parental adults and positive youth development across mid-to lateadolescence: The moderating effect of parenting profiles, Journal of Youth and Adolescence, 2014, 43(6), pp. 897-918. DOI https://doi.org/10.1007/s10964-014-0095-x

[46] Stoltenborgh, M., van IJzendoorn, M. H., Euser, E.M., \& Bakermans-Kranenburg, M. J., Aglobal perspective on child sexual abuse: Meta-analysis of prevalence around the world, Child Maltreatment, 2011, 16(2), pp. 79-101. DOI:https://doi.org/10.1177/1077559511403920

[47] Jain, S., Cohen, A. K., Kawashima-Ginsberg, K., 
Duarte, C. D. P., \& Pope, A., Civic engagement among youth exposed to community violence: Directions for research and practice.Journal of Youth Development, 2019, 14(1), 24-47. DOI: https://doi.org/10.5195/jyd.2019.596

[48] Storer, H. L., McCleary, J. S., \& Hamby, S., When it's safer to walk away: Urban, low opportunity emerging adults' willingness to use bystander behaviors in response to community and dating violence, Children and Youth Services Review, 2021, 121. DOI: https://doi.org/10.1016/j.childyouth.2020.1053 